Kong. Res. J. 1(2): 116-120, 2014

Kongunadu Arts and Science College, Coimbatore

\title{
ETHNOMEDICINAL STUDIES ON RIVER STRETCH CAUVERY BASIN OF NANJAI EDAYAR AND KUCHIPALAYAM, NAMAKKAL DISTRICT, TAMIL NADU
}

\author{
Thirumaran, G., ${ }^{* 1}$ C.M. Ganesan ${ }^{2}$ and K. Nandakumar ${ }^{1}$ \\ ${ }^{1}$ Department of Botany, Kandaswami Kandar's College, Velur, Namakkal. \\ ${ }^{2}$ Department of Botany, Kongunadu Arts and Science College, Coimbatore. \\ *Email: thirubotany@gmail.com
}

\begin{abstract}
The study area covers about $15 \mathrm{~km}$ stretch in the perennial river bed, Cauvery which supports semievergreen to dry deciduous types of forests. Ethnomedicinal information on 26 plant species was recorded during the extensive field survey carried out in this stretch during 2011-2013. The information covers botanical names, vernacular names, family, plant parts used and the mode of usage.
\end{abstract}

Key words: Cauvery river basin; Medicinal plants; Traditional uses.

\section{INTRODUCTION}

Ethnobotanical studies carried out by varies workers have recorded that the tribal communities of India use about 7500 species of plants for a variety of medicinal purposes (Anonymous, 1994). In India, about 2500 plant species belonging to more than 1000 genera are used by traditional herbal healers and about 500 plant species are used by 159 different pharmaceutical companies (Chandel et al., 1996; Vibhuti et al., 2009). The large bulk of traditional knowledge of ethnic and rural people of India is handed down to generation through word of mouth and is extensively used for the treatment of common diseases and conditions (Ekka et al., 2007). Primitive and village people of Namakkal district have been using several plants for combating disease from centuries and are found wide acceptance in traditional medicinal use. By the proper identification and documentation of such plants which are used in local treatment can help in developing easily available materials for the treatment of varies diseases as well as raising the health standards of the village people.

\section{Study area}

The Cauvery river stretch between Nanjai edayar and Kuchipalayam areas of Namakkal district Tamilnadu is situated at $11^{\circ} 04^{\prime} \mathrm{L}$ and $78^{\circ} 03^{\prime} \mathrm{E}$. The altitude is 130.45 above MSL. The soil is mostly sandy with slightly acidic $\mathrm{pH}$. The local public living in the adjoining villages in addition to western medicine also using herbal medicines for their day to day life. The present study was undertaken to document the traditional uses of medicinal plants available between Nanjai edayar and Kuchipalayam villages of Cauvery river basin in Tamilnadu. Grasslands, man-made plantation and semi- evergreen to dry deciduous types of forests are the common vegetations in this belt.

\section{MATERIALS AND METHODS}

The present study work was carried out in the study areas described during the period of 20112013. The forest areas and other vegetation were sampled for species identification near the villages viz., Kuchippalayam, Velur, Nanjai edayar, Sengappalli and Palappatti.

A field survey was done in these villages for the plant based traditional medicinal practices and their uses. It consists of information interviewing of the villager's through the prepared questionnaire, who generally depend upon forests for their food and health and other needs of day to day life.

The identified and collected plant samples were arranged and documented according to their binomial. The traditional and the modern processing techniques of the medicinal plant species are enquired and briefed well. The total respondents were 4-6 in numbers per village. The species of medical importance were identified with the help of 'The Flora of Presidency of Madras' (Gamble, 19151935), The Flora of Tamilnadu Carnatic (Mathew 1983) and Indian Medicinal Plants (Kirtikar \& Basu, 2003). Voucher specimens of the plants collected during the study were deposited in the Herbarium of the Department of Botany, Kandaswami Kandar's College, Velur, Namakkal, Tamilnadu.

\section{RESULTS AND DISCUSSION}

According to a report of World Health Organization, over $3 / 4$ of world population relies on the use of traditional medicine of plant origin (Rai et al., 2000). The traditional medicine has a long history and wide acceptability. Therefore, 
documentation of information on indigenous knowledge and practices will help in conserving the traditional knowledge (Gani, 2003). The present enumeration shows the occurrence of 26 plant species of 25 genera belonging to 21 families (Table. 1). The study provides comprehensive information on the indigenous uses and traditional practices of the plants used in household remedies. All the 26 species documented were known to have intense use for the local public in the study villages. Species like Abrus precatorius, Dendrophthoe falcata and Heliotropium indicum are being used for wound healing purposes. Interestingly the species, Catharanthus roseus is used for its anticancer property. Similarly the species, Gymnema sylvestre is used for the treatment of diabetics and Zizypus jujuba is used for the treatment of jaundice. The species, Ocimum scantum is having mosquitosidal property. The two species, Cassia tora and Terminalia catappa are prescribed for skin diseases and the species, Cassia occidentalis is used for the treatment of eye problems.

The study revealed that the Cauvery stretch between the Nanjai edayar and Kuchipalayam contains the vegetation rich in medicinal species which indicates the potentiality of this region in terms of traditional medicinal flora wealth. Therefore, sustainable utilization and effective conservation are supported to utilize and protect the species.

\section{REFERENCES}

Anonymous. (1994). IUCN Red List categories IUCN, Gland Switzerland.

Ajay, B. and S. Nema, (2014). Ethnomedical practices and indigenous household remedies used by the tribals and rurals of the Bastar Region, Indian Forester, 140(2) : 192-200, 2014.
Chandel, K.P., S.G. Shukla and S. Neelam, (1996). Biodiversity in Medicinal and Aromatic Plants in India; Conservation and utilization NBPGR, New Delhi: 239.

Ekka, N.R. and V.K. Dixit, (2007). Ethnopharmacognostical studies of medicinal plants of jashpur district, Chattishgarh, Int. j. of Green phar, 1(1): 2-4.

Gamble, J.S. 1915-1935 Vols 1-3. Flora of Presidency of Madras, BSI, Calcutta.

Gani, A. (2003). Medicinal plants of Bangladesh with chemical constituents and uses. $2^{\text {nd }}$ edition, Asiatic society of Bangladesh, 5 old Secretariate road, nimtali, Bangladesh.

Harish kumar et. al; (2012). Ethnomedicinal uses of plants of Chhot and Bara Bhangal areas of district Kangra, Himachal Pradesh. Ethnobotany; 24: 126-131.

Kirtikar, K.R. and B.D. Basu. (2003). Indian Medicinal plants. Second Edition in Eleven Volumes. Oriental Enterprises, Dehradun, Uttaranchal, India.

Matthew, K.M. Vols. 1-3. The Flora of Tamilnadu carnatic, The Rapinat Herbarium, St. Joseph's College, Tiruchirapalli, India.

Pullaiah. T. (2002). Vos. 1-2 Medicinal plants in India. Regency Publications, New Delhi.

Raj, L.K.; Prasad Pankaj and Sharma, E. 2000. Conservation threat to some important medicinal plants of the Sikkim Himalaya, Biol. Conserve; 93:27-33.

The Wealth of India, (2006). Vols.1-5, Council for Scientific and industrial Research, New Delhi. 


\begin{tabular}{|c|c|c|c|c|}
\hline Botanical name & Local name & Family & Parts used & Ethnomedicinal uses \\
\hline Abrus precatorius L. & Gundumani & Fabaceae & $\begin{array}{l}\text { Leaves, } \\
\text { Roots, Seeds }\end{array}$ & $\begin{array}{l}\text { *Fresh or dry leaes are ground and the infusion mixed with water is } \\
\text { given orally once a day for three for menorrhoea.* Leaves of the white } \\
\text { seed variety mixed with garlic, ground and the paste is given thrice a } \\
\text { days for treating leucorrhoea. }{ }^{*} \text { The roots are also used to cure } \\
\text { leucoderma, itching and wounds. *Seeds are poisonous, used by the } \\
\text { locals to avoid pregnancy. }\end{array}$ \\
\hline Acalypha indica L. & Kuppaimeni & Euphorbiaceae & Leaves & $\begin{array}{l}{ }^{*} \text { Fresh leaves mixed with black pepper, garlic and long pepper, ground } \\
\text { in water and the infusion given orally 3-6 times a day for the treatment } \\
\text { of post-natal body pains. }\end{array}$ \\
\hline Aegle marmelos L. & Vilvam & Rutaceae & Fruits & $\begin{array}{l}\text { *The fruit is used in chronic diarrhoea and dysentery and said to at as a } \\
\text { tonic for heart and brain. }\end{array}$ \\
\hline Annona squamosa L. & Seethapazham & Annonaceae & $\begin{array}{l}\text { Bark, } \\
\text { Leaves, } \\
\text { Roots, Fruits }\end{array}$ & $\begin{array}{l}\text { *The bark is used in diarrhoea. }{ }^{*} \text { The root is employed in depression } \\
\text { and spinal diseases, in asthma and fever. }{ }^{*} \text { The cursed leaves are } \\
\text { reported to be applied to the nostrils in hysteria and fits. }{ }^{*} \text { The fruit } \\
\text { possesses astringent, cooling, anti-scorbutic, and febrifugal properties. } \\
\text { *Fruits is a source of vitamin C. }\end{array}$ \\
\hline $\begin{array}{l}\text { Alternanthera sessilis(L.) } \\
\text { DC. }\end{array}$ & Ponnaankanni & Amaranthaceae & Herb & $\begin{array}{l}\text { *The herb is used as a galactogogue, cholagogue, abortifacient and } \\
\text { febrifuge. It is also used as a indigestion. }{ }^{*} \text { The whole plant is bitter, } \\
\text { sweet, cooling and constipating. It is used to treat burning sensation, } \\
\text { diarrhoea, leprosy, skin diseases, night blindness, dyspepsia and fever. }\end{array}$ \\
\hline Aloe vera(L.) Burm.f. & Katarezhai & Liliaceae & $\begin{array}{l}\text { Leaves and } \\
\text { Roots }\end{array}$ & $\begin{array}{l}\text { *Leaf pulp used to treat liver disorders, rheumatism, skin disorders, } \\
\text { Vanishing cream, emollient, intestinal worms. *The leaf-gel has } \\
\text { demand in cosmetic industry abroad and is also used to treat radiation } \\
\text { burns. }\end{array}$ \\
\hline $\begin{array}{l}\text { Azadirachta indica A. } \\
\text { Juss. }\end{array}$ & Vembu & Meliaceae & $\begin{array}{l}\text { Bark, } \\
\text { Leaves, } \\
\text { seeds }\end{array}$ & $\begin{array}{l}{ }^{*} \text { Neem oil has been found to slow down the growth of HIV-virus which } \\
\text { causes AIDS. }{ }^{*} \text { The emulsified oil is used to control rust on beans and } \\
\text { powdery mildew on many ornamental plants. }{ }^{*} \text { A handful of leaves, } \\
\text { crushed and flattened, will make an excellent poultice for boils and } \\
\text { sores; its action is stimulant and antiseptic. }\end{array}$ \\
\hline $\begin{array}{l}\text { Bacopa monnieri (L.) } \\
\text { Pennel }\end{array}$ & Brahmi & Scrophulariaceae & Entire plant & $\begin{array}{l}\text { *The entire plant constitutes the well-known drug Brahmi. It is used in } \\
\text { the indigenous systems of medicine for the treatment of asthma, } \\
\text { hoarseness, insanity, epilepsy, and as a potent nerve tonic, cardiotonic } \\
\text { and diuretic. It is also used as a laxative, in several skin diseases and in } \\
\text { bronchitis. }\end{array}$ \\
\hline
\end{tabular}




\section{Calophyllum inophyllum}

L.

\section{Calotropis gigantea (L.)}

R.Br

Cardiospermum

halicacabum L.

Cassia occidentalis L.

Nattam-takarai

Caesalpiniaceae

Entire plant

\section{Leaves} ,Roots

\section{Catharanthus roseus (L.) Sudukattu}

G.Don.

mallikai

Apocynaceae

Entire plant

Ceiba pentandra (L.)

Gaertn.

Ilavam

Bombacaceae

Fruits, Roots

${ }^{*}$ A paste of the kernels is applied to relieve painful joints. ${ }^{*}$ The refined oil is intramuscularly injected to alleviate pain in leprosy.*The oil cures scabies and other coetaneous diseases. ${ }^{*}$ The pounded bark is applied in orchitis and its juice is taken as purgative. *The leaves are employed for inhalation in migraine and vertigo.

*The root bark constitutes the drug. The powdered root bark gives relief in diarrhoea and dysentery. It is also given in cough and asthma, and as a febrifuge.

*The herb is diuretic, stomachic and rubefacient. It is used in rheumatism, lumbago, nervous diseases, as a demulcent in orchitis and dropsy. *The root is mucilaginous and considered effective in didymitis and early stages of hydrocele, and is used in asthma and colic.

*All parts of the plant possess purgative, tonic, febrifugal, expectorant and diuretic properties. ${ }^{*}$ The plant is used to cure sore eyes,

haematuria, rheumatism, typhoid, asthma and disorders of hemoglobin. *The herb forms an ingredient of the patented indigenous herbal drug "Liv-52", which shows marked effect in the early cases of hepatic cirrhosis having ciatorrhoea.

*Both leaves and seeds constitute a valuable remedy in skin diseases, chiefly for ringworm and itch. *The weed is used in various Gold Coast medicines, chiefly as a purgative. ${ }^{*}$ The root is not an antidote to either snake-venom or scorpion-venom.

*The roots, which form the drug, contain more than 80 alkaloids of which Indole-Indoline dimers are pharmacologically very important.

*Vinca alkaloids received great attention due to anticancer potential. Vincristine and Vinblastine are used as anticancer drugs especially for curing leukemia (blood cancer).

*The roots are stimulant, tonic, diuretic, emetic and antispasmodic; they have hypoglycemic effect and are useful in diabetes, dysentery and gonorrhoea. ${ }^{*}$ The unripe pods are astringent and demulcent, useful in vertigo and migraine. ${ }^{*}$ The gum is given in bowel complaints and gonorrhoea.

*As anesthetic in surgery and child birth, in ophthalmology and prevention of motion sickness.

*The bark is astringent and narcotic, and is used for wounds and menstrual troubles and also as a remedy for asthma and mania. ${ }^{*}$ The

\begin{tabular}{|c|c|c|c|c|}
\hline Datura innoxia Mill. & Umathai & Solanaceae & Seeds & $\begin{array}{l}{ }^{*} \text { As anesthetic in surgery and child birth, in ophthalmology and } \\
\text { prevention of motion sickness. }\end{array}$ \\
\hline $\begin{array}{l}\text { Dendrophthoe falcata } \\
\text { (L.f.) Etting }\end{array}$ & Pulluruvi & Loranthaceae & Bark & $\begin{array}{l}\text { *The bark is astringent and narcotic, and is used for wounds and } \\
\text { menstrual troubles and also as a remedy for asthma and mania. *The }\end{array}$ \\
\hline
\end{tabular}




\begin{tabular}{|c|c|c|c|c|}
\hline Euphorbia hirta L. & $\begin{array}{l}\text { Amam } \\
\text { patchaiarisi }\end{array}$ & Euphorbiaceae & Entire plant & $\begin{array}{l}\text { constitutes the drug. It is useful in removing worms in children, in } \\
\text { bowel complaints, asthma and cough. *It promotes formation and flow } \\
\text { of milk in Woman; it is also useful in gonorrhoea and other } \\
\text { urinogenitary complaints. The roots of the plant stop vomiting. }\end{array}$ \\
\hline Gloriosa superba L. & Kanthal malar & Liliaceae & Seeds, Roots & $\begin{array}{l}\text { *The tubers are regarded as tonic, somatic and antheimintic when } \\
\text { taken in doses of } 5-10 \text { grains; in larger, doses they are intensely } \\
\text { poisonous. Root tubers and seeds rich source of colchicine. *Colchicine } \\
\text { is used in the treatment of cancer. }\end{array}$ \\
\hline $\begin{array}{l}\text { Gymnema sylvestre } \\
\text { (Retz.) R.Br. Ex Schult. }\end{array}$ & Ciru kurinjan & Asclepiadaceae & $\begin{array}{l}\text { Leaves, } \\
\text { Roots }\end{array}$ & $\begin{array}{l}\text { *The leaves used for treating diabetes. The plant is stomachic, } \\
\text { stimulant, laxative and diuretic. The roots are emetic and expectorant. }\end{array}$ \\
\hline Heliotropium indicum L. & Nakkipoo & Boraginaceae & Leaves & $\begin{array}{l}\text { *The leaf juice is used as an application to wounds, sores, boils, gum- } \\
\text { boils and to repel pimples on the face; boiled with castor oil it is } \\
\text { applied to bites of scorpions, insects and reptiles. It is also employed } \\
\text { locally in the kind of ophthalmic in which the tarsus is inflamed or } \\
\text { excoriated. }\end{array}$ \\
\hline Mangifera indica $\mathrm{L}$. & Mampazham & Anacardiaceae & $\begin{array}{l}\text { Leaves, } \\
\text { Fruits }\end{array}$ & $\begin{array}{l}\text { *Decoction of the leaves is used in fever, diarrhoea and toothache. }{ }^{*} \text { The } \\
\text { dried mango peel can be used as a fuel for biogas plants. *The bio gas } \\
\text { plant effluents are then used as a substitute for conventional fish feed. }\end{array}$ \\
\hline Ocimum sanctumL. & Tulasi & Lamiaceae & $\begin{array}{l}\text { Leaves, } \\
\text { Seeds, Roots }\end{array}$ & $\begin{array}{l}\text { *The plants drive away mosquitoes. It is useful in avarity of diseases. } \\
\text { *Leaves ground with water are applied on bed boils. *Powder of the } \\
\text { root rubbed slightly on a scorpion bite will give relief from pain. It basil } \\
\text { root is taken, } 1 \mathrm{gm} \text { weight, at eve, increases the vital fluid and will } \\
\text { bestow retentive virtue. Nerve weakness may be cured by it. }\end{array}$ \\
\hline Pergularia daemia L. & Vealipparutthi & Asclepiadaceae & Entire plant & $\begin{array}{l}\text { *The juice from the tender vegetative parts is used to cure toothache } \\
\text { by the village people of Namakkal district. }\end{array}$ \\
\hline Terminalia catappa L. & Kadookkai & Combretaceae & Leaves & $\begin{array}{l}\text { *Leaf juice of young leaves is used to prepare an ointment for skin } \\
\text { diseases. }\end{array}$ \\
\hline Zizypus jujuba L. & Elandai & Rhamanaceae & Bark, Roots & $\begin{array}{l}\text { The fruits juice has cooling effect, and its syrup is used to cure jaundice } \\
\text { and other abdominal diseases. Bark is used for Teeth diseases and flu. }\end{array}$ \\
\hline
\end{tabular}

